\title{
CAMINHOS DE UMA REPÓRTER
}

Realidade viva da rua pulsa no concerto entre palavra e imagem, orquestradas na reportagem

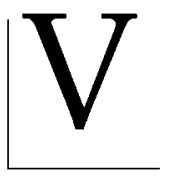

irei jornalista por causa do cheiro. Nunca sonhei: quero ser jornalista. Queria ser detetive, Ivanhoé, qualquer coisa heróica assim. Mas o cheiro me pegou. Explico, quando estava no colégio (o Macedo Soares, na Barra Funda, em São Paulo) fomos fazer uma visita à redação da Folha de S. Paulo (era 1967, e eu estava no primeiro colegial) que ficava ali pertinho, na alameda Barão de Limeira. Assim que entrei no prédio senti aquele cheiro do papel e da tinta, as máquinas trabalhando. Depois a redação escura e a Helena Silveira circulando por ali. Fiquei encantada e para sempre marcada com aquela imagem de filme de detetives dos anos 50 , de divisórias de vidro canelado e madeira marrom escura. $\mathrm{O}$ mundo a ser descoberto por aqueles aventureiros, desbravadores.
Não era nada disso, claro, o mundo do jornalismo não tinha nada de heróico. Sempre trabalhei na editoria que se convencionou chamar de geral e depois, na televisão, todo repórter é da geral, assim fui ficando especialista em superficialidades. Hoje aprender sobre transplante, amanhã sobre a ponte que rachou, depois de amanhã um seqüestro, na quinta feira, um show do Funk Como Le Gusta. E assim nunca havia tempo para se aprofundar em nada e muito pouco a ser descoberto. A minha sensação era de que os repórteres eram uma porção de pessoas que topavam ir a lugares a que a maioria da população não queria ir, mas queria saber o que acontecia lá.

Havia, no entanto, uma coisa que me dava grande prazer: era procurar rapidamente soluções de imagem e de texto que criassem o clima para a reportagem que 
eu estava fazendo. E aquele tempo desesperadamente curto me dava mais e mais oportunidades de ser cada vez mais rápida. Era preciso. E aquilo virou um encantamento. Quantas vezes, a caminho do local da reportagem, eu ia sonhando e imaginando o que poderia fazer, que imagem poderia ser a mais significativa para aquele assunto. Às vezes não servia para nada, fiz muitas bobagens nesse caminho, mas sempre valeu a pena, porque sempre tive muito prazer em ser repórter de televisão.

Trabalhei três anos na Folha de S. Paulo, quinze na TV Globo, um ano e meio no SBT e há três anos, desde 1998, estou na TV Cultura, dirigindo o programa $\mathrm{Ca}$ minhos e Parcerias.

Quando comecei a trabalhar na Globo, nunca mais me interessei pelo jornalismo impresso. Tudo que aprendi foi na Globo. Entrei lá em 1980, numa época em que a redação de São Paulo (e do Rio também) era um laboratório onde as idéias novas ferviam, nasciam e as chefias davam espaço para a criatividade de todo mundo.

Aquela foi a minha universidade, ali aprendi $95 \%$, os outros $5 \%$ acho que aprendi na faculdade de jornalismo (certamente por minha culpa, na época trabalhava em teatro e estava mais interessada em ser atriz) da FAAP - 1970/1973.

Nesse longo aprendizado na TV Globo pude descobrir a importância da palavra. Todo mundo dizia: "uma imagem vale mais do que mil palavras", mas para mim não era isso. Até o dia em que o repórter cinematográfico da Globo, Marco Antônio Gonçalves, me ensinou uma coisa que nunca mais esqueci. "A diferença entre uma imagem comum e uma boa imagem é que a boa imagem tem texto. Quando estou filmando, penso num texto e ele faz sentido com aquela imagem, essa é a prova de que aquela é uma boa imagem".

Eestá cheio de imagens lindas por aí, que não dizem nada, porque não têm texto, porque só têm luz bonita, bom enquadramento, mas é preciso mais do que isso.

\section{TEXTO E IMAGEM: UM SÓ OLHAR}

O texto também não pode ser um texto qualquer, tem de ser um texto que revele o que a imagem não diz. O que a imagem só dirá junto com determinadas palavras. E parecerá uma surpresa, uma novidade.

Para que esse conjunto de coisas funcione é preciso que o repórter trabalhe grudado com o cinegrafista. O olhar da câmera tem de representar o olhar do cinegrafista, somado ao olhar do repórter. Só uma integração perfeita resulta num grande trabalho.

No Globo Repórter aprendi a fazer programas longos sem roteiro prévio. Discutíamos a pauta: diretor, repórter, produtor e saíamos para gravar, depois de tudo gravado, assistíamos a todas as fitas que eram transcritas na íntegra e em cima disso eu escrevia o roteiro e o texto final. Até hoje trabalho assim.

Não gosto do roteiro feito antes porque acredito que isso limita a ação da reportagem. A rua sempre será mais rica que a redação.

$\mathrm{Na}$ rua tudo muda, quase nada que imaginamos é real, porque não existe nada mais vibrante, mais louco e transformador do que a realidade. 
Quando chego nos lugares de gravação procuro me entregar àquela situação, de forma que o entrevistado é quem acaba me ensinando as perguntas que devo lhe fazer. Essa é uma primeira fase: a de recolher dados. Às vezes gravo coisas que parecem não ter nada a ver com o assunto. Quantas vezes o cinegrafista que estava trabalhando comigo me perguntava: "mas aonde você vai usar isso?" Eu nunca soube responder e nunca saberei. Porque aquele é o momento de pegar coisas, juntar cacos. Estou apenas coletando. O norte é feito de fragmentos. Tenho pedaços de programa, como em um sonho. Só poderei reconhecer a importância e o lugar daquilo quando estiver fazendo o roteiro.

A segunda fase, tão importante quanto a primeira, é a decupagem das fitas. A transcrição literal. Só uma decupagem perfeita resultará em um bom roteiro. Decupagem é trabalho para profissional, para quem tem amor pela edição, por juntar detalhes. Mesmo quando estou decupando não abandono nada. Não tem nada que eu possa dizer com garantia: isso não vai entrar. $\mathrm{O}$ universo inteiro (imagens, entrevistas) me acompanha o tempo todo.

Com a decupagem nas mãos começa a terceira fase: escrever o roteiro e o texto final. Começa um tempo de silêncio. Um mergulho no caos e uma caminhada até a luz e a ordem. E esse é um processo interior. Toda vez me sinto assim: caótica e, aos poucos, enquanto o roteiro vai tomando forma, eu também vou encontrando meu lugar no mundo. É como se o roteiro fosse se fazendo sozinho, as coisas vão se apresentando, como se tivessem vida própria e depois de uma coisa só pode vir aquela outra. A mim só cabe prestar aten- ção onde entra um texto, onde entra uma música. A música nos meus programas é como o texto, tem o mesmo peso, a mesma participação.

Penso nas imagens e o texto nasce em função daquelas imagens. Na verdade é como um círculo, o texto influencia a imagem e a imagem influencia o texto e não se sabe quem veio primeiro. $O$ texto nasce por causa de uma imagem, mas na hora da filmagem a imagem também nasce em função de um texto que, de alguma forma, já se anunciava. Mas isso tudo é método, jeito de trabalhar, para um é bom, para outro não serve para nada.

\section{LIÇÃO PARA A VIDA DE JORNALISTA}

A lição fundamental na minha vida de jornalista tive agora depois de vinte e tantos anos de profissão. Descobri agora na TV Cultura, fazendo o Caminhos e Parcerias. Nunca vi com tanta clareza o que precisava fazer, o que queria dizer, o que era importante destacar. Pela primeira vez, descobri que era possível seguir um caminho com o qual eu tinha sonhado, mas nem sabia que tinha sonhado. Só percebi o caminho quando estava nele.

Percebi que sempre haverá espaço para que se possa dizer o que se acredita. Ninguém dará isso a você. É preciso encontrar as frestas e trabalhar nas frestas.

Será sempre pouco ou nada o que darão a você, mas é com esse pouco, ou com esse 
nada que é preciso encontrar o caminho. Porque ele estará lá à espera de ser descoberto. À espera de ser percorrido. E quem conseguir ver o caminho, mesmo que seja pelo vão mais ínfimo, precisa segui-lo. Estará para sempre comprometido com o caminho que vislumbrou. E terá de fazêlo tornar-se real.

Foi isso que aconteceu comigo no Caminhos e Parcerias. Quando o diretor de jornalismo da TV Cultura, Marco Antônio Coelho Filho, convidou-me para dirigir o programa, ele disse: "um programa sobre comunidades". Eu pensei: "ai que chato, eu queria fazer documentários sobre artistas plásticos, sobre museus, grandes obras de arte"...mas respondi: "aceito". Pensei: "começo com isso depois saio e vou fazer os documentários sobre arte que é o que me interessa".

Primeiro programa: Mirandiba, sertão de Pernambuco. Lá fui eu e a equipe de cinco pessoas. Estrada do sertão. Paramos um casal que viajava numa carroça puxada a burro. "Onde fica Mirandiba"? "Ah são novato aqui, é ? Mirandiba fica pra lá, vira ali, pra aqui...", enfim, mil informações, no final o senhor olhou pra gente e disse: "tive muito prazer", e a mulher: "Nossa Senhora da Guia leve vocês na mão de Deus".

Era só uma informação, mas ao indicar o caminho para a cidade, indicaram também o caminho para a minha vida. Naquele momento vi um vão, uma fresta por onde caminhar. Aquela era a arte que eu buscava, aquela era a poesia (o povo do sertão fala em poesia, não em prosa, como nós), aquela era a ética, o respeito, o belo. Eram aquelas as pessoas que precisavam ter voz na televisão, ter voz com dignidade e beleza, para serem reconhecidas em toda a sua humanidade.

Era aquele o Brasil que eu queria ver na TV.
Resumo: O artigo trata do depoimento da jornalista Neide Duarte sobre sua opção pelo jornalismo e sua trajetória profissional. A autora relata como desenvolveu um método de trabalho para a edição de imagem e texto de suas reportagens. Aponta a importância da palavra para a leitura dos sentidos da imagem. Fala de seu atual trabaIho como diretora do Programa Caminhos e Parcerias, na TV Cultura - SP

Palavras-chave: telejornalismo, reportagem, roteiro, imagem, palavra
(The paths of a reporter)

Abstract: The article presents the statement of journalist Neide Duarte on why she opted for journalism and on her professional trajectory. The author comments on how she developed a unique work approach to edit image and text in her reports. She points to the importance of the word for one to read the meanings of the image and talks about her current position as the director of the Caminhos e Parcerias (Paths and Partnerships) Program, at TV Cultura - SP

Key words: broadcast news, reports, agen$\mathrm{da}$, image, word 